UDC 633.11:664.661

Original research paper

\title{
TEXTURE AND STRESS RELAXATION OF SPELT-AMARANTH COMPOSITE BREADS
}

\author{
Bojana V. Filipčev* \\ University of Novi Sad, Institute of Food Technology, Bulevar cara Lazara 1, 21000 Novi Sad, Serbia
}

${ }^{*}$ Corresponding author:
Phone: +381214853778
Fax: +38121450725
E-mail address: bojana.filipcev@fins.uns.ac.rs

ABSTRACT: This study compares the influence of different forms of amaranth (steamed and nonsteamed raw amaranth flour, steamed and non-steamed popped amaranth flour and steamed whole popped amaranth grains) at two doses on quality attributes of composite spelt-amaranth breads. Besides the usual, well established, empirical parameters, fundamental mechanical properties of crumb (stress relaxation) were also assessed. Positive effects on bread characteristics (significantly increased specific volume, softer crumb) were shown by raw amaranth flour and steamed whole popped amaranth grain addition. The addition of raw amaranth flour also contributed to better crumb resilience. The results showed that stress relaxation data obtained from both Peleg-Normand and Maxwell models provided fairly good correlation with empirical quality parameters which confirms their potential to properly describe the changes in bread quality.

Key words: spelt, amaranth, composite bread, quality, stress relaxation

\section{INTRODUCTION}

In recent times there has been a great interest in organically produced wheat bread. Spelt wheat is frequently used for these purposes since spelt possesses several agronomic characteristics that make it suitable for organic production. Bread made from spelt is usually inferior compared to bread made from conventional wheat and this inferiority is mainly related to lower loaf volume and impaired crumb textural properties whereas it offers similar or even better nutritional value. However, similarly to wheat, spelt amino acids are not optimally balanced for human nutrition due to deficiency in lysine. Spelt products are versatile and beside bread include pasta, ready-to-eat cereals, seedlings (Pasqualone et al., 2011), frozen bakery products (Šimurina, 2011), crackers (Filipčev et al., 2012) cookies, snacks, etc. Nevertheless, there is a perma- nent need to broaden the assortment of organic bakery products.

Composite bakery products may offer manifold advantages; from extended bakery assortment to improved nutritive value. The main concept of the composite flour program launched in 1964 by world health authorities was to search for nonwheat compounds which in combination with flour would give formulations offering optimal nutritive value and appropriate processing characteristics. Composite products have high potential for development of functional products and a number of alternative cereals including amaranth are in focus for development of value-added bakery products (Sedej, 2011). It was inferred by many researches the adequacy of grain amaranth in combination with wheat flour (de la Barca et al., 2010; Grobelnik Mlakar et al., 2009b; Lacko- 
Bartošová and Korczyk-Szabó, 2012; Sanz-Penella et al., 2013). Upon summoning the results, it could be concluded that the most authors confirmed the supplementation levels between $10-20 \%$ as the most appropriate for composite breads. At the mentioned doses, bread quality attributes were observed to mainly deteriorate (specific volume decrease, crumb hardness increase) but to acceptable level whereas nutritional value improved significantly. However, only in few reports, speltamaranth mixtures were addressed. Grobelnik Mlakar et al. (2008) investigated the baking potential of composite wholemeal spelt/wholemeal amaranth flour and reported that at $10 \%$ substitution level, bread loaf volume was not negatively influenced and that texture and aroma were not impaired up to $30 \%$ substitution level. Also, it was reported that the addition of amaranth flour to common wheat, refined spelt or wholemeal spelt flour tended to stabilize dough and increase its resistance (Grobelnik Mlakar et al., 2009a). LackoBartošová and Korczyk-Szabó (2012) basically confirmed the positive effect of amaranth flour addition on rheological properties of spelt dough.

Research works dealing with composite wheat-amaranth formulations mainly elaborated the addition of amaranth flour (either in the form of raw (native) or hyperproteic flour). Only several works were related to application of other forms of amaranth. Bodroža-Solarov et al. (2008) and de la Barca et al. (2010) investigated the addition of whole popped amaranth grain to bread whereas Hernández et al. (2012) investigated combinations of raw and popped amaranth flour in processing of gluten-free bread.

The primary objective of the present study was to investigate the breadmaking potential of spelt-amaranth composite flours which encompassed versatile forms of the amaranth component (steamed and nonsteamed raw amaranth flour, steamed and non-steamed popped amaranth flour and steamed whole popped amaranth grains). The breadmaking potential was evaluated by observing the most important quality aspects of bread (crumb texture and loaf volume) measuring empirical textural para- meters (crumb hardness, crumb resilience) and fundamental mechanical properties of crumb (stress-relaxation). Thus, the second objective of this study was to describe the stress relaxation behavior of composite breads and to estimate its suitability to discern differences among various breads as well as to investigate the correlation between empirical and fundamental textural properties.

\section{MATERIAL AND METHODS}

\section{Bread preparation}

Spelt flour was supplied from ecological agricultural farm "Jevtić", Bačko Gradište, Serbia. Amaranth grain was purchased from a local market. Amaranthus cruentus species was used in this study. Amaranth grain was popped on an aluminium hot plate at $200{ }^{\circ} \mathrm{C}$ for $10 \mathrm{~s}$. Amaranth flour was obtained by milling whole amaranth grain on a Bühler laboratory mill (Bühler $A G$, Switzerland). Flour passages $A$ and $B$ were combined in a single sample whereas bran fractions were discarded. Popped amaranth flour was obtained by milling popped amaranth grains on a hammer mill type Lab Mill 3100 Perten (Sweden).

Bread preparation was based on a basic formulation that contained (on flour basis): $100 \%$ spelt flour, $2.5 \%$ fresh compressed yeast, $2 \%$ salt, and $0.050 \mathrm{~g} / \mathrm{kg}$ ascorbic acid. Water was added to achieve consistency of 400 B.U. according to farinogram. Composite spelt-amaranth breads were elaborated by substitution of spelt flour with either $10 \%$ or $20 \%$ of amaranth in various forms: steamed and nonsteamed raw amaranth flour, steamed and non-steamed milled popped amaranth and steamed popped amaranth. This has yielded nine different formulations of composite breads and one control without amaranth addition. A modified breadmaking procedure used in this study is described in detail in the work of Filipčev et al., 2013. The duration of final fermentation time was estimated by experienced baker and varied among different bread formulations ranging between 55 and 70 $\min$.

\section{Bread quality tests}

Volume of bread loaves was determined using a millet seed displacement method. 
Bread crumb firmness was determined according to the standard AACCI 74-10A method (AACCI, 2009) using a $36 \mathrm{~mm}$ diameter probe. Crumb resilience was determined as a percentage of recovery of sample's height in relation to its initial height after maximal compression at $60 \%$ strain during 2 seconds followed by a recovery period of $15 \mathrm{~s}$.

\section{Stress relaxation test}

Stress relaxation test was conducted on a texture analyzer TA-XTplus (Stable Micro Systems, Surrey, England) equipped with a stainless steel probe $36 \mathrm{~mm}$ (diameter). Bread samples were compressed with the probe to a $12 \%$ strain at $1 \mathrm{~mm} / \mathrm{s}$ pretest and $0.5 \mathrm{~mm} / \mathrm{s}$ test speed. The loading was kept constant during $600 \mathrm{~s}$. The reaction force and stress-time history was recorded during the test. The obtained stress relaxation curves were subjected to analysis using the Peleg-Normand and Maxwell models.

\section{Statistical analysis}

Statistical analysis was performed using the software package Statistica 12 (StatSoft, Inc., Tulsa, OK). Fisher's LSD test was used to differentiate means between the samples. Non-linear regression analysis (Levenberg-Marquardt method) was used to process stress relaxation data.

\section{RESULTS AND DISCUSSION}

\section{Bread properties}

Table 1 shows the major quality characterristics of breads obtained by the addition of different forms of amaranth grains at $10 \%$ and $20 \%$ dose. All observed parameters were significantly affected by type and dose of ingredients but without clear trends within the majority of different formulations. Specific volume ranged from $2.90 \mathrm{ml} / \mathrm{g}$ to $3.68 \mathrm{ml} / \mathrm{g}(3.47 \mathrm{ml} / \mathrm{g}$ for the control).

Samples containing 20\% steamed popped amaranth flour, $10 \%$ and $20 \%$ popped amaranth flour and $10 \%$ steamed amaranth flour had significantly lower specific volume than the control. Only the addition of $10 \%$ raw amaranth flour or steamed whole popped grains resulted in a signi- ficantly higher specific volume. In relation to the control, significantly softest crumb was presented by samples containing $20 \%$ raw amaranth flour and $10 \%$ steamed whole popped grains whereas significantly harder crumb was observed in breads with popped flour $(10,20 \%), 10 \%$ steamed flour and $20 \%$ steamed popped flour. Resilience is an important quality feature of bread crumb which reflects its ability to regain its original position after deformation. Significantly higher crumb resilience relative to the control was shown in sample with $10 \%$ raw amaranth flour. Significant worsening of crumb elastic properties was found in formulations that contained $20 \%$ of any of the steamed variants of amaranth. Despite little clear trends, the results pointed out that the addition of raw amaranth flour and steamed popped whole amaranth grains positively influenced bread attributes by significantly increasing specific volume and improving the viscoelastic crumb properties. The only exception was that steamed popped whole amaranth grains at $20 \%$ dose did not contribute to better resilience but significantly lowered it in relation to the control.

\section{Stress relaxation}

Stress relaxation of composite spelt-amaranth breads was conducted to investigate the suitability of stress relaxation parameters to characterize differences among the breads. The stress relaxation curves show the decaying behavior characteristic for most viscoelastic materials (Fig. 1). PelegNormand and generalized Maxwell model were used for data fitting. The obtained fitting parameters are presented in Table 2.

The reciprocal of the $k_{1}$ value in the PelegNormand model represents the initial rate of relaxation. High $\mathrm{k}_{1}$ values indicate low decay rate associated with pronounced elastic behavior. The $k_{1}$ values in composite spelt-amaranth breads ranged from 51 to 65. So far, this constant has not been considered as a reliable parameter to discern viscoelastic properties as it is surmised to depend on numerous other factors such as sample shape, and experimental errors (Buňka et al., 2013; Peleg, 1979, 1980; Singh et al., 2006). 


\section{Table 1.}

Quality characteristics of spelt-amaranth breads (specific volume, crumb hardness and crumb resilience)

\begin{tabular}{cccc}
\hline $\begin{array}{c}\text { Spelt-amaranth } \\
\text { bread }\end{array}$ & $\begin{array}{c}\text { Specific volume } \\
(\mathbf{m l} / \mathbf{g})\end{array}$ & Hardness $(\mathbf{g})$ & Resilience (\%) \\
\hline 00 & $3.47^{\mathrm{c}, \mathrm{d}}$ & $845.48^{\mathrm{b}, \mathrm{c}, \mathrm{d}}$ & $67.24^{\mathrm{c}, \mathrm{d}, \mathrm{e}}$ \\
01 & $3.64^{\mathrm{e}, \mathrm{f}}$ & $778.83^{\mathrm{a}, \mathrm{b}, \mathrm{c}}$ & $76.39^{\mathrm{g}}$ \\
02 & $3.53^{\mathrm{d}, \mathrm{e}}$ & $637.95^{\mathrm{a}}$ & $69.27^{\mathrm{d}, \mathrm{e}, \mathrm{f}}$ \\
03 & $3.10^{\mathrm{b}}$ & $1120.37^{\dagger}$ & $71.83^{\mathrm{e}, \mathrm{f}, \mathrm{g}}$ \\
04 & $3.10^{\mathrm{b}}$ & $1088.2^{\mathrm{e}, \mathrm{t}}$ & $73.40^{\mathrm{t}, \mathrm{g}}$ \\
05 & $2.98^{\mathrm{a}, \mathrm{b}}$ & $1098.3^{\mathrm{e}, \mathrm{t}}$ & $66.28^{\mathrm{c}, \mathrm{d}}$ \\
06 & $3.48^{\mathrm{d}}$ & $705.59^{\mathrm{a}, \mathrm{b}}$ & $56.62^{\mathrm{b}}$ \\
07 & $3.68^{\dagger}$ & $675.94^{\mathrm{a}}$ & $68.68^{\mathrm{d}, \mathrm{e}, \mathrm{f}}$ \\
08 & $3.39^{\mathrm{c}, \mathrm{d}}$ & $906.88^{\mathrm{c}, \mathrm{d}}$ & $55.08^{\mathrm{a}, \mathrm{b}}$ \\
09 & $3.33^{\mathrm{c}}$ & $945.22^{\mathrm{d}, \mathrm{e}}$ & $62.34^{\mathrm{c}}$ \\
10 & $2.90^{\mathrm{a}}$ & $1654.91^{\mathrm{e}}$ & $50.12^{\mathrm{a}}$ \\
\hline
\end{tabular}

a,b,c,... Significant at $\mathrm{p} \leq 0.05$ (LSD test).

Sample designation: 00-control bread; 01, 02:10/20\% raw amaranth flour; 03, 04: 10/20\% popped amaranth flour; 05, 06: 10/20\% steamed amaranth flour; $07,08: 10 / 20 \%$ steamed whole popped amaranth grains; $09,10: 10 / 20 \%$ steamed popped amaranth flour

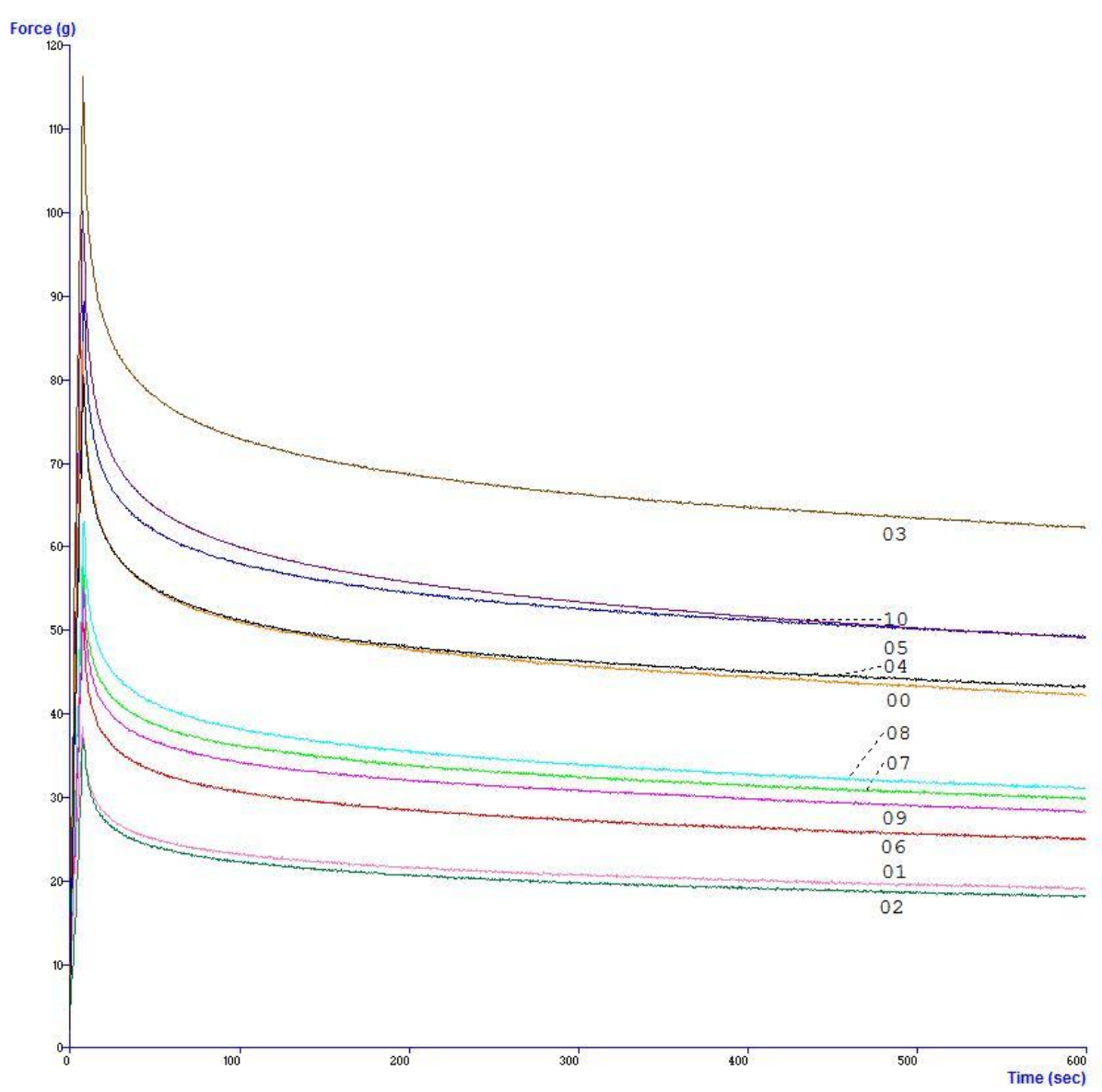

Figure 1. Stress relaxation curves for different formulations of composite spelt-amaranth breads

Sample designation: 00: control bread; 01, 02: 10/20\% raw amaranth flour; 03, 04: 10/20\% popped amaranth flour; 05, 06: 10/20\% steamed amaranth flour; 07, 08: 10/20\% steamed whole popped amaranth grains; 09, 10: $10 / 20 \%$ steamed popped amaranth flour 
Even so, some authors found that this parameter was able to detect the differences among various samples e.g. among cooked spaghetti with rising content of resistant starch in the work of Sozer et al., 2008 or among cooked Asianstyle noodles made from various common and durum wheat in the work of Hatcher et al. (2008) showing that $\mathrm{k}_{1}$ was highly correlated to the springiness of high-fiber steamed breads.

Mandala et al. (2007) reported medium strong but significant correlation between crust moisture and $k_{1}$ in wheat breads formulated with various hydrocolloids.

Results obtained from our set of samples support the former statement on the inadequacy of this parameter to follow the textural changes since no significant correlation was found between $\mathrm{k}_{1}$ and any of the quality parameters of composite breads (Table 3).

Constant $\mathrm{k}_{2}$ is related to the residual stress in the material and describes the level to which stresses decay during relaxation. Thus, it indicates the solid nature of material although Singh et al. (2006) expect that, in food, $k_{2}$ is a better indicator of elasticity than solidity. For composite spelt-amaranth breads, $\mathrm{k}_{2}$ spanned in the range 1.53-2.15. It was not significantly correlated to bread quality parameters but it is worth noting that there was weak negative correlation with specific volume $(r=-0.42)$. Also, correlations of similar intensities were found between $\mathrm{k}_{2}$ and \%SR and $F_{\max }$ showing that $k_{2}$ carries some information on both solidity and elasticity of the material. The existence of moderate, although non-significant, correlation $(r=0.53)$ with $\mathrm{Fe}$ supports the statement that $k_{2}$ is an indicator of residual stress and elastic nature in material.

Percentage stress relaxation (\%SR) is another informative parameter extracted directly from the stress relaxation curve at an arbitrary time. It describes the extent of relaxation. As ideal elastic material never decays, \%SR is 0 , whereas for ideal liquid $\%$ SR is $100 \%$. In spelt-amaranth breads, $\%$ SR ranged from $44.88-53.53 \%$. Similar range of \%SR values (40-50\%) for baked products were reported by Singh et al. (2006) \%SR was significantly highly and inversely $(r=-0.71)$ correlated to crumb resilience showing that less elastic crumb is less able to recover deformation. The results confirm that \%SR has an ability to well reflect the elastic properties of bread crumb. $F_{\max }$ is an initial force needed to deform the sample at a given strain and it indicates the hardness of material. Indeed, $F_{\max }$ was highly positively $(r=0.85)$ to crumb hardness. In addition, it was inversely correlated to specific volume because larger loaves were softer.

Stress relaxation curves can be analyzed using the generalized Maxwell model. The decay forces $\left(F_{1}, F_{2}\right.$ and $\left.F_{3}\right)$ were highly positively correlated to hardness and $F_{\text {max }}$ showing that these parameters carried information on the rigidity i.e. solid nature of the sample (Table 3). It was as well strongly inversely correlated to the specific volume. Relaxation time $\left(\lambda_{1}, \lambda_{2}, \lambda_{3}\right)$ in the Maxwell model measures the relaxation time of Maxwell elements. Its physical meaning is related to the time needed to stretch bonds in macromolecules during deformation. Shorter relaxation times are associated with less elastic behaviour and higher rigidity. In our set of samples, three relaxation times were characteristic: at longer time 191.62-698 s; at intermediate time 17.17-42.13 $\mathrm{s}$ and at short time 1.80$3.53 \mathrm{~s}$.

Relaxation times were strongly inter correlated showing that they carry the same type of information. Faster relaxation phase $\lambda_{3}$ was found to be significantly correlated to crumb resilience $(r=0.61)$ whereas others showed moderate but insignificant correlation. This shows that relaxation times are upon a certain degree sensitive to elastic properties of bread crumb and harmonizes with the finding of $\mathrm{Wu}$ et al. (2012) who found that $\lambda$ was correlated to the springiness of steamed breads.

Since the third term $\lambda_{3}$ represents the shortest relaxation time in the model, it seems that crumb resilience measured as a percentage of crumb height recovery after removal of load registers the shorttime response of bread crumb. 
Table 2.

Relaxation curve parameters of Peleg-Normand and 3-element Maxwell model for composite spelt-amaranth breads

\begin{tabular}{|c|c|c|c|c|c|c|c|c|c|c|c|}
\hline \multirow{2}{*}{$\begin{array}{c}\text { Spelt- } \\
\text { amaranth } \\
\text { bread }\end{array}$} & \multicolumn{4}{|c|}{ Peleg-Normand model } & \multicolumn{7}{|c|}{ 3-element Maxwell model } \\
\hline & $\begin{array}{l}k_{1} \\
(s)\end{array}$ & $\mathbf{k}_{2}$ & $\begin{array}{l}\text { \%SR } \\
\text { (\%) }\end{array}$ & $\begin{array}{c}F_{\text {max }} \\
(g)\end{array}$ & $\begin{array}{l}F_{1} \\
(g)\end{array}$ & $\begin{array}{l}F_{2} \\
(g)\end{array}$ & $\begin{array}{l}F_{3} \\
(g)\end{array}$ & $\begin{array}{l}\lambda_{1} \\
\text { (s) }\end{array}$ & $\begin{array}{l}\lambda_{2} \\
\text { (s) }\end{array}$ & $\begin{array}{l}\lambda_{3} \\
\text { (s) }\end{array}$ & $\begin{array}{l}F_{e} \\
(g)\end{array}$ \\
\hline 00 & $52.49^{a}$ & $1.90^{b, c, d}$ & $51.12^{\mathrm{c}, \mathrm{d}}$ & $86.23^{\mathrm{c}, \mathrm{d}}$ & $13.92^{d}$ & $13.61^{c}$ & $16.81^{\mathrm{d}, \mathrm{e}, \mathrm{f}}$ & $208.67^{\mathrm{a}}$ & $17.38^{\mathrm{a}, \mathrm{b}}$ & $1.94^{\mathrm{a}, \mathrm{b}, \mathrm{c}}$ & $42.16^{d}$ \\
\hline 01 & $53.62^{\mathrm{a}, \mathrm{b}}$ & $1.89^{\mathrm{b}}$ & $51.70^{\mathrm{c}, \mathrm{d}}$ & $39.18^{\mathrm{a}}$ & $7.62^{\mathrm{a}}$ & $5.79^{\mathrm{a}}$ & $8.80^{a, b}$ & $698.08^{\mathrm{C}}$ & $42.13^{\mathrm{d}}$ & $3.53^{\mathrm{e}}$ & $15.80^{\mathrm{a}}$ \\
\hline 02 & $50.91^{\mathrm{a}}$ & $1.53^{\mathrm{a}}$ & $52.68^{\mathrm{c}, \mathrm{d}}$ & $39.01^{\mathrm{a}}$ & $6.68^{\mathrm{a}}$ & $6.32^{\mathrm{a}}$ & $7.86^{\mathrm{a}}$ & $201.21^{\mathrm{a}}$ & $17.17^{\mathrm{b}}$ & $2.11^{\mathrm{a}, \mathrm{b}, \mathrm{c}}$ & $18.14^{\mathrm{a}, \mathrm{b}}$ \\
\hline 03 & $56.87^{\mathrm{b}, \mathrm{c}}$ & $2.10^{c, d}$ & $46.31 a$ & $116.37^{\mathrm{e}, \mathrm{f}}$ & $20.93^{\mathrm{e}}$ & $21.23^{\mathrm{d}}$ & $23.33^{\dagger}$ & $197.00^{\mathrm{a}}$ & $18.48^{\mathrm{b}}$ & $1.97^{\mathrm{a}, \mathrm{b}, \mathrm{c}}$ & $75.53^{\dagger}$ \\
\hline 04 & $61.85^{\mathrm{d}, \mathrm{e}}$ & $2.10^{c, d}$ & $46.15 a$ & $80.60^{b, c, d}$ & $12.89^{\mathrm{c}, \mathrm{d}}$ & $11.68^{\mathrm{b}, \mathrm{c}}$ & $12.89^{b, c, d}$ & $191.62^{\mathrm{a}}$ & $18.83^{\mathrm{b}}$ & $2.23^{\mathrm{c}}$ & $43.29^{d}$ \\
\hline 05 & $65.42^{\dagger}$ & $2.15^{\mathrm{d}}$ & $44.88 a$ & $89.63^{\mathrm{d}, \mathrm{e}, \mathrm{t}}$ & $13.88^{d}$ & $12.30^{\mathrm{b}, \mathrm{c}}$ & $14.17^{\mathrm{c}, \mathrm{d}}$ & $191.82^{\mathrm{a}}$ & $17.55^{\mathrm{a}, \mathrm{b}}$ & $2.14^{\mathrm{b}, \mathrm{c}}$ & $49.28^{d, e}$ \\
\hline 06 & $54.27^{\mathrm{a}, \mathrm{b}}$ & $1.86^{\mathrm{b}}$ & $52.03^{\mathrm{c}, \mathrm{d}}$ & $52.08^{\mathrm{a}, \mathrm{b}}$ & $9.10^{\mathrm{a}, \mathrm{b}}$ & $8.35^{a, b}$ & $9.087^{\mathrm{a}, \mathrm{b}}$ & $196.92^{\mathrm{a}}$ & $16.60^{\mathrm{a}}$ & $1.80^{\mathrm{a}}$ & $25.05^{a, b, c}$ \\
\hline 07 & $64.67^{\mathrm{e}, \mathrm{t}}$ & $1.99^{\mathrm{b}, \mathrm{c}, \mathrm{d}}$ & $51.78^{\mathrm{c}, \mathrm{d}}$ & $57.92^{\mathrm{a}, \mathrm{b}, \mathrm{c}}$ & $10.11^{\mathrm{a}, \mathrm{b}, \mathrm{c}}$ & $8.33^{a, b}$ & $10.86^{a, b, c}$ & $357.01^{\mathrm{b}}$ & $26.83^{\mathrm{c}}$ & $2.69^{a}$ & $28.02^{\mathrm{b}, \mathrm{c}}$ \\
\hline 08 & $58.98^{\mathrm{c}, \mathrm{d}}$ & $1.89^{\mathrm{b}, \mathrm{c}, \mathrm{d}}$ & $51.53^{\mathrm{c}, \mathrm{d}}$ & $63.7^{\mathrm{a}, \mathrm{b}, \mathrm{c}, \mathrm{d}}$ & $11.43^{\mathrm{b}, \mathrm{c}, \mathrm{d}}$ & $10.13^{a, b, c}$ & $11.02^{\mathrm{a}, \mathrm{b}, \mathrm{c}}$ & $203.94^{\mathrm{a}}$ & $16.49^{\mathrm{a}}$ & $1.88^{\mathrm{a}, \mathrm{b}}$ & $31.00^{c}$ \\
\hline 09 & $62.14^{\mathrm{d}, \mathrm{e}, \mathrm{t}}$ & $1.99^{\mathrm{b}}$ & $48.99^{\mathrm{b}}$ & $55.31^{\mathrm{a}, \mathrm{b}}$ & $9.31^{\mathrm{a}, \mathrm{b}, \mathrm{c}}$ & $8.32^{\mathrm{a}, \mathrm{b}}$ & $9.03^{a, b}$ & $213.62^{\mathrm{a}}$ & $16.57^{\mathrm{a}}$ & $1.82^{\mathrm{a}, \mathrm{b}}$ & $28.27^{\mathrm{b}, \mathrm{c}}$ \\
\hline 10 & $51.16^{\mathrm{a}}$ & $1.81^{\mathrm{b}}$ & $53.53^{\mathrm{d}}$ & $121.88^{\dagger}$ & $21.36^{\mathrm{e}}$ & $23.17^{\mathrm{d}}$ & $20.77^{e, t}$ & $197.73^{\mathrm{a}}$ & $17.28^{\mathrm{b}}$ & $1.97^{\mathrm{a}, \mathrm{b}, \mathrm{c}}$ & $56.67^{\mathrm{e}}$ \\
\hline
\end{tabular}

a,b,c,... Significant at $\mathrm{p} \leq 0.05$ (LSD test).

00-control bread; 01, 02:10/20\% raw amaranth flour; 03, 04: 10/20\% milled popped amaranth grains; 05, 06: 10/20\% steamed amaranth flour; 07, 08: 10/20\% steamed popped amaranth grains; 09, 10: 10/20\% steamed milled popped amaranth grains 
Table 3.

Correlation of stress-relaxation parameters with quality characteristics of composite breads

\begin{tabular}{|c|c|c|c|c|c|c|c|c|c|c|c|c|c|c|}
\hline & WA & $\begin{array}{c}V_{s p} \\
(\mathrm{ml} / \mathrm{g})\end{array}$ & $\begin{array}{l}\text { Hard- } \\
\text { ness } \\
\text { (g) }\end{array}$ & $\begin{array}{l}\text { Resili- } \\
\text { ence } \\
(\%)\end{array}$ & $k_{1}$ & $k_{2}$ & \%SR & $F_{\max }$ & $F_{1}$ & $F_{2}$ & $F_{3}$ & $\lambda_{1}$ & $\lambda_{2}$ & $\lambda_{3}$ \\
\hline $\begin{array}{c}W A \\
V_{\text {sp }}(\mathrm{ml} / \mathrm{g})\end{array}$ & $\begin{array}{c}1.00 \\
-0.10\end{array}$ & 1.00 & & & & & & & & & & & & \\
\hline $\begin{array}{l}\text { Hardness } \\
\text { (g) }\end{array}$ & -0.16 & $-0.89^{\star}$ & 1.00 & & & & & & & & & & & \\
\hline $\begin{array}{c}\text { Resilience } \\
(\%)\end{array}$ & $0.76^{*}$ & 0.30 & -0.42 & 1.00 & & & & & & & & & & \\
\hline $\begin{array}{l}\mathrm{k}_{1} \\
\mathrm{k}_{2}\end{array}$ & $\begin{array}{l}0.02 \\
0.03\end{array}$ & $\begin{array}{l}-0.14 \\
-0.42\end{array}$ & $\begin{array}{l}-0.05 \\
0.28\end{array}$ & $\begin{array}{l}0.18 \\
0.23\end{array}$ & $\begin{array}{l}1.00 \\
\mathbf{0 . 7 4 ^ { * }}\end{array}$ & 1.00 & & & & & & & & \\
\hline$\% S R$ & -0.50 & -0.04 & 0.05 & -0.71 & -0.14 & -0.45 & 1.00 & & & & & & & \\
\hline$F_{\max }$ & -0.09 & $-0.82^{\star}$ & $0.85^{\star}$ & -0.24 & -0.01 & 0.43 & 0.05 & 1.00 & & & & & & \\
\hline $\mathrm{F}_{1}$ & -0.12 & $-0.78^{\star}$ & $0.84^{\star}$ & -0.27 & -0.08 & 0.38 & 0.02 & $0.99^{\star}$ & 1.00 & & & & & \\
\hline$F_{2}$ & -0.13 & $-0.77^{\star}$ & $0.85^{\star}$ & -0.32 & -0.18 & 0.27 & 0.08 & $0.97^{\star}$ & $0.99^{\star}$ & 1.00 & & & & \\
\hline $\mathrm{F}_{3}$ & -0.04 & $-0.68^{\star}$ & $0.73^{\star}$ & -0.12 & -0.14 & 0.36 & -0.04 & $0.96^{\star}$ & $0.97^{\star}$ & $0.96^{*}$ & 1.00 & & & \\
\hline$\lambda_{1}$ & 0.06 & 0.53 & -0.30 & 0.48 & -0.10 & -0.05 & -0.51 & -0.45 & -0.38 & -0.41 & -0.33 & 1.00 & & \\
\hline$\lambda_{2}$ & 0.13 & 0.49 & -0.28 & 0.54 & -0.05 & 0.01 & -0.54 & -0.39 & -0.33 & -0.37 & -0.27 & $0.99^{\star}$ & 1.00 & \\
\hline$\lambda_{3}$ & 0.24 & 0.45 & -0.27 & 0.61 & 0.02 & 0.02 & -0.50 & -0.39 & -0.35 & -0.39 & -0.29 & $0.95^{\star}$ & $0.98^{*}$ & 1.00 \\
\hline $\mathrm{F}_{\mathrm{e}}$ & 0.08 & $-0.79^{\star}$ & $0.72^{\star}$ & -0.08 & 0.08 & 0.53 & -0.09 & $0.96^{\star}$ & $0.95^{\star}$ & $0.92^{\star}$ & $0.96^{\star}$ & -0.46 & -0.40 & -0.40 \\
\hline
\end{tabular}

* Significant at $p \leq 0.05$ 
It has been implicated that smaller molecule structures in the dough are involved with shorter relaxation times (Hernández et al., 2012).

Equilibrium stress $F_{e}$ in the Maxwell model showed strong correlation to specific volume and crumb hardness. There was a moderate correlation $(r=0.53)$ between $k_{2}$ and $F_{e}$ but it was not significant showing that $\mathrm{k}_{2}$ may be partly interpreted as an indicator of residual stress in the sample.

\section{CONCLUSION}

Although little clear trends could be observed in the effect of various forms of amaranth compound, positive effects on bread quality attributes were exerted by raw amaranth flour and steamed whole popped amaranth grain which increased the specific volume and softened the crumb. The only difference in the effects between these two forms was a decrease in crumb resilience for steamed popped amaranth at higher substitution level.

The results showed that stress relaxation data are suitable in observing the differences among various composite spelt-maranth breads. In the Peleg-Normand model, $F_{\max }$ was strongly correlated to crumb hardness and loaf volume whereas \%SR was well correlated to crumb resilience. In the generalized Maxwell model, crumb hardness and loaf volume were strongly correlated to decay and equilibrium forces. Relaxation times showed some correlation to crumb resilience.

The existence of strong and medium correlations between the stress relaxation parameters and bread quality attributes indicates that stress relaxation profile reflects well the mechanical properties of bread.

\section{ACKNOWLEDGEMENT}

This work is a part of research conducted within project III 46005 supported by the Ministry of Education, Science and Technological Development of the Republic of Serbia.

\section{REFERENCES}

1. American Association of Cereal Chemists (AACCI, A.A.o.C.C.I., (2009). AACC International Approved Methods, 11th Edition, Method 7410.02 Measurement of bread firmness-compression test. AACC International, St. Paul, Mn, USA.

2. Bodroža-Solarov, M., Filipčev, B., Kevrešan, Ž., Mandić, A.M., Šimurina, O. (2008). Quality of bread supplemented with popped grains of Amaranthus cruentus. Journal of Food Process Engineering, 31, 602-618.

3. Buňka, F., Pachlová, V., Pernická, L., Burešová, I., Kráčmar, S., Lošák, T. (2013). The dependence of Peleg's coefficients on selected conditions of a relaxation test in model samples of Edam cheese. Journal of Texture Studies, 44, 187-195.

4. de la Barca, A.M.C., Rojas-Martínez, M.E., IslasRubio, A.R., Cabrera-Chávez, F. (2010). Glutenfree breads and cookies of raw and popped amaranth flours with attractive technological and nutritional qualities. Plant Foods in Human Nutrition, 65, 241-246.

5. Filipčev, B., Bodroža-Solarov, M., Brkljača, J. (2012). Characterization of organically grown spelt cultivars for cracker-making applications. Food \& Feed Research, 39, 61-68.

6. Filipčev, B., Šimurina, O., Bodroža-Solarov, M., Obreht, D. (2013). Comparison of the breadmaking performance of spelt varieties grown under organic conditions in the environment of northern Serbia and their responses to dough strengthening improvers. Hem. Ind., 67, 443-453.

7. Grobelnik Mlakar, S., Bavec, M., Turinek, M., Bavec, F. (2009a). Rheological properties of dough made from grain amaranth-cereal composite flours based on wheat and spelt. Czech Journal of Food Science, 27, 309-319.

8. Grobelnik Mlakar, S., Turinek, M., Jakop, M., Bavec, M., Bavec, F. (2008). Organically produced grain amaranth-spelt composite flours. II Bread Quality, in Proceedings of the $43^{\text {rd }}$ Croatian and $3^{\text {rd }}$ international Symposium on Agriculture. University of Zagreb, Faculty of Agriculture, Zagreb, Croatia, Opatija, Croatia, pp. 92-95.

9. Grobelnik Mlakar, S., Turinek, M., Jakop, M., Bavec, M., Bavec, F. (2009b). Nutrition value and use of grain amaranth: potential future application in bread making. Agricultura, 6, 43-53.

10. Hatcher, D.W., Bellido, G.G., Dexter, J.E., Anderson, M.J., Fu, B.X. (2008). Investigation of uniaxial stress relaxation parameters to characterize the texture of yellow alkaline noodles made from durum and common wheats. Journal of Texture Studies, 39, 695-708.

11. Hernández, Z.J.E., Figueroa, J.D.C., RayasDuarte, P., Martínez-Flores, H.E., Arámbula, G.V., Luna, G.B., Arámbula, G.V. (2012). Influ- 
ence of high and low molecular weight glutenins on stress relaxation of wheat kernels and the relation to sedimentation and rheological properties. Journal of Cereal Science, 55, 344-350.

12. Lacko-Bartošová, M., Korczyk-Szabó, J. (2012). Technological properties of spelt-amaranth composite flours. Research Journal of Agricultural Science, 44, 90-93.

13. Mandala, I., Karabela, D., Kostaropoulos, A. (2007). Physical properties of breads containing hydrocolloids stored at low temperature. I. Effect of chilling. Food Hydrocolloids, 21, 1397-1406.

14. Pasqualone, A., Piergiovanni, A.R., Caponio, F., Paradiso, V.M., Summo, C., Simeone, R. (2011). Evaluation of the tehnological characteristics and bread-making quality of alternative wheat cereals in comparison with common and durum wheat. Food Science and Technology International, 17, 135-142.

15. Peleg, M. (1979). Characterization of the stress relaxation curves of solid foods. Journal of Food Science, 44, 277-281.

16. Peleg, M. (1980) Linearization of relaxation and creep curves of solid biological materials. Journal of Rheology 24, 451-463.
17. Sanz-Penella, J.M., Wronkowska, M., SoralSmietana, M., Haros, M. (2013). Effect of whole amaranth flour on bread properties and nutritive value. LWT-Food Science and Technology, 50, 679-685.

18. Sedej, I. (2011). Functional and antioxidant properties of new buckwheat products. Food \& Feed Research, 38, 27-31.

19. Singh, H., Rockall, A., Martin, C.R., Chung, O.K., Lookhart, G.L. (2006). The analysis of stress relaxation data of some viscoelastic foods using a texture analyzer. Journal of Texture Studies, 37, 383-392.

20. Sozer, N., Kaya, A., Dalgic, A.C. (2008). The effect of resistant starch addition on visco-elastic properties of cooked spaghetti. Journal of Texture Studies, 39, 1-16.

21. Šimurina, O. (2011). The effect of basic raw materials in the process of wheat dough freezing. Food \& Feed Research, 38, 9-19.

22. Wu, M.-Y., Chang, Y.-H., Siau, S.-Y., Chen, C.-C. (2012). Rheology of fiber-enriched steamed bread: stress relaxation and texture profile analysis. Journal of Food and Drug Analysis, 20, 133-142.

\title{
ТЕКСТУРНА И СТРЕС РЕЛАКСАЦИОНА СВОЈСТВА КОМПОЗИТНИХ СПЕЛТА-АМАРАНТУС ХЛЕБОВА
}

\author{
Бојана В. Филипчев \\ Универзитет у Новом Саду, Научни институт за прехрамбене технологије у Новом Саду, \\ 21000 Нови Сад, Булевар цара Лазара бр. 1, Србија
}

Сажетак: У овом раду се испитује утицај додатка различитих фрорми амарантуса-штира (парено и обично брашно од штира, парено и обично брашно од кокица штира и парене целе кокице штира) у две дозе на квалитет композитних спелта-амарантус хлебова. Поред уобичајених, добро познатих емпиријских параметара, у раду су праћена и фундаментална механичка својства средине хлеба (стрес релаксациона својства). Позитиван ефекат на запремину и мекоћу средине хлеба је имао додатак непареног брашна од штира и парених кокица штира, с тим да је додатак брашна побољшавао и еластичност средине за разлику од кокица. Резултати су показали да стрес релаксациони показатељи добијени применом оба модела (по Пелег-Норману и Максвелу) показују добре корелације са емпиријским параметрима квалитета хлеба, што потврђује да могу да адекватно опишу промене квалитета хлеба настале додатком различитих форми штира у формулацији хлеба од спелта пшенице.

Кључне речи: спелта, штир, композитни хлеб, квалитет, стрес релаксација

Received: 27 September 2013

Accepted: 20 January 2014 